\title{
Chemical composition of endemic Centaurea austro-anatolica and studies of its antimicrobial activity against multi-resistant bacteria
}

\author{
AYSEL UGUR ${ }^{*}$ \\ NURDAN SARAC ${ }^{2}$ \\ OZGUR CEYLAN ${ }^{3}$ \\ M. EMIN DURU ${ }^{4}$ \\ ${ }^{1}$ Department of Biology, Faculty \\ of Arts and Sciences, Mugla University \\ 48121 Kotekli-Mugla, Turkey \\ 2 Medical Laboratory Program \\ Vocational School of Health Services \\ Mugla University \\ 48700 Marmaris-Mugla, Turkey \\ ${ }^{3}$ Department of Nursing \\ Health College, Usak University \\ 64100 Usak, Turkey \\ ${ }^{4}$ Department of Chemistry \\ Faculty of Arts and Sciences \\ Mugla University \\ 48121 Kotekli-Mugla, Turkey
}

\begin{abstract}
Hexane, chloroform, ethyl acetate and ethanolic extracts of the aerial parts of Centaurea austro-anatolica Hub.-Mor. (Asteraceae) were evaluated against microorganisms, including multiresistant bacteria, using a paper disc diffusion method. The chloroform extract exhibited significant antibacterial activity toward all bacteria tested. The chemical composition of the chloroform extract was determined by gas chromatography (GC) and gas chromatography-mass spectrometry (GC-MS). The major compounds of the extract were caryophyllene oxide $(21.32 \%)$, spathulenol (10.86\%), n-tricosanol (9.58\%) and geranyl isovalerate $(8.71 \%)$.
\end{abstract}

Keywords: Centaurea austro-anatolica (Asteraceae), chemical composition, antimicrobial activity

Accepted Semptember 15, 2009

Many members of the genus Centaurea have been long used in Anatolian folk medicine (1). Various Centaurea species have certain biological properties, such as antimicrobial (2), antifungal (3), anti-inflammatory (4), anti-ulcerogenic (5), antioxidant (6), antiviral (7), anti-Helicobacter pylori (8), antiprotozoal (2), anticancer and cytotoxic properties (9).

\footnotetext{
* Correspondence; e-mail: ayselugur@hotmail.com
} 
A. Ugur et al: Chemical composition of endemic Centaurea austro-anatolica and studies of its antimicrobial activity against multi-resistant bacteria, Acta Pharm. 59 (2009) 463-472.

C. austro-anatolica is an endemic species distributed in the Aegean region of Turkey and is an East-Mediterranean element (10). The aim of this study was to identify the chemical composition and to evaluate the antimicrobial activity of the extracts of C. austro-anatolica against different microorganisms, including multi-resistant bacteria. The plant species was selected because many species of this genus are used in traditional medicine for various purposes and because of the absence of phytochemical and biological studies of C. austro-anatolica.

\section{EXPERIMENTAL}

\section{Chemicals}

Silicagel 60, used for column chromatography, and Kieselgel 60F254, used for TLC as precoated plates, $n$-hexane, chloroform, ethyl acetate and methanol were obtained from Merck (Germany). Reference standards used for co-injection in GC $\alpha$-cubebene (purity $97 \%$ ), $\beta$-bourbonene (purity $\geq 98 \%$ ), spathulenol (purity $\geq 98 \%$ ), $n$-tricosanol (purity $\geq 97 \%$ ), $n$-heptacosanol (purity $\geq 98 \%$ ), 2-decenal (purity $\geq 95 \%$ ), caryophyllene oxide (purity $\geq 90 \%$ ), 2-buthyl-1-octanol (95\%) and $\beta$-eudesmol (purity $\geq 90 \%$ ) were purchased from Fluka and Sigma-Aldrich (USA). Ascaridole (purity $\geq 97 \%$ ) ascariole epoxide (purity $\geq 96 \%$ ), cubenol (purity $\geq 97 \%$ ), ledene oxide-(II) (purity $\geq 96 \%$ ), and hexahydro farnesyl acetone (purity $\geq 96 \%$ ) were obtained from the Department of Chemistry, Faculty of Sciences and Arts, University of Mugla, Turkey.

\section{Plant material and crude extracts}

C. austro-anatolica naturally growing plants belonging to Asteraceae were collected at the flowering stage from Mugla, Turkey. A voucher specimen has been deposited in the Herbarium of the Faculty of Arts and Sciences, University of Mugla, Turkey. The plant was identified immediately after collection and air-dried at room temperature for later analysis.

The air dried and powdered aerial parts of C. austro-anatolica were extracted successively with hexane, chloroform, ethyl acetate and ethanol in a Soxhlet apparatus until the last portion of the extract became colorless. Solvents of all extracts were removed under low vacuum by using rotary evaporation. Crude extracts were maintained at $+4{ }^{\circ} \mathrm{C}$ until use. Crude extracts were investigated for antimicrobial activity.

\section{Chemical composition of the chloroform extract}

Column chromatography. - For CC, silica-gel $60(63-210 \mu \mathrm{m})$ was used as adsorbent in a column and mobile phases were 95:5, 90:10 and 85:15 hexane/acetone systems. The fractions were purified by TLC and subjected to GC and GC-MS analysis.

Gas chromatography (GC). - GC analysis of the extract was performed using a Shimadzu GC-17 AAF, V3, 230V LV (Japan) series gas chromatograph equipped with a FID and a DB-5 fused silica capillary column $(30 \mathrm{~m} \times 0.32 \mathrm{~mm}$ i.d., film thickness $0.25 \mu \mathrm{m})$. 
A. Ugur et al: Chemical composition of endemic Centaurea austro-anatolica and studies of its antimicrobial activity against multi-resistant bacteria, Acta Pharm. 59 (2009) 463-472.

The initial oven temperature was kept at $100{ }^{\circ} \mathrm{C}$ for $5 \mathrm{~min}$, then programmed to $240{ }^{\circ} \mathrm{C}$ at $3{ }^{\circ} \mathrm{C} \mathrm{min}-1$ and kept at this temperature for $30 \mathrm{~min}$; injector and detector temperatures were 250 and $270{ }^{\circ} \mathrm{C}$, respectively. Carrier gas was He at a flow rate of $1.4 \mathrm{~mL} \mathrm{~min}{ }^{-1}$, sample size was $1.0 \mu \mathrm{L}$, split ratio was 50:1. The percentage composition of the chloroform extract was recorded using the Class-GC 10 computer program.

Gas chromatography-mass spectrometry (GC/MS). - Solution of the dry chloroform extract in $\mathrm{CHCl}_{3}\left(50 \mathrm{mg} \mathrm{mL}^{-1}\right)$ was prepared for GC and GC-MS analyses. The analysis of the extract was performed using a Varian Saturn 2100 (Varian, USA) equipped with a Agilent DB-5 MS fused silica capillary column (Agilent Technologies, USA) $(30 \mathrm{~m} \times 0.32$ $\mathrm{mm}$ i.d., film thickness $0.25 \mu \mathrm{m}$ ). For GC-MS detection, an electron ionization system with ionization energy of $70 \mathrm{eV}$ was used. Carrier gas was helium at a flow rate of $1.7 \mathrm{~mL}$ $\mathrm{min}^{-1}$. Injector and MS transfer line temperatures were set at $220^{\circ} \mathrm{C}$ and $290{ }^{\circ} \mathrm{C}$, respectively. The oven temperature was kept at $100{ }^{\circ} \mathrm{C}$ for $5 \mathrm{~min}$, then increased to $240{ }^{\circ} \mathrm{C}$ with $3{ }^{\circ} \mathrm{C} \mathrm{min}-1$ increment and maintained at this temperature for $25 \mathrm{~min}$. Diluted samples $(1 / 100, V / V$, in methylene chloride) $(1.0 \mu \mathrm{L})$ were injected manually in the splitless mode. The relative percentage of extract constituents was expressed as percentage by peak area normalization.

The compounds were identified by using NIST 2002, Wiley library data of GC-MS systems and a locally customized library of 320 spectra, as well as by comparison with the fragmentation patterns of the mass spectra with those reported in the literature (11) and, whenever possible, using reference substances, by co-injection with authentic compounds.

\section{Antimicrobial assay}

Microorganisms and cultivation conditions. - Gram-negative bacteria Enterobacter aerogenes RSKK 720, Pseudomonas aeruginosa ATCC 27853 and Escherichia coli ATCC 25922, Gram-positive bacteria Micrococcus luteus NRRL B-4375, Bacillus subtilis ATCC 6633, Streptococcus mutans CNCTC 8/77 and Staphylococcus aureus ATCC 25923, yeasts Candida albicans ATCC 10239, Candida tropicalis RSKK 665 and multi-resistant strains of S. maltophilia and various species of Staphylococcus, including coagulase negative Staphylococci (CNS), were used. The multi-resistant bacteria were obtained from the Mugla University Culture Collection.

The above mentioned bacteria, except $S$. mutans, were cultured in Nutrient Broth (NB) (Difco, USA), S. mutans was cultured in Brain Heart Infusion Broth (BHIB) (Difco), C. albicans and C. tropicalis were cultured in Sabouraud Dextrose Broth (SDB) (Difco). P. aeruginosa and S. maltophilia strains and the fungi were incubated at $30 \pm 0.1^{\circ} \mathrm{C}$ for $18-24$ $\mathrm{h}$ and $24-48 \mathrm{~h}$, respectively. Other bacteria were incubated at $37 \pm 0.1^{\circ} \mathrm{C}$ for $24-48 \mathrm{~h}$. Inocula were prepared by adjusting the turbidity of the medium to match the $0.5 \mathrm{McFar}-$ land standard dilutions of this suspension in $0.1 \%$ peptone $(\mathrm{m} / \mathrm{V})$ solution in sterile water inoculated on $\mathrm{NB}, \mathrm{BHIB}, \mathrm{SDB}$ to check the viability of the preparation. The cultures of microorganisms were maintained in their appropriate agar slants at $4{ }^{\circ} \mathrm{C}$ throughout the study and used as stock cultures.

Disc diffusion assay. - The antibacterial activity was based on the disc diffusion method $(12,13)$ using a bacterial cell suspension whose concentration was equilibrated to 
A. Ugur et al: Chemical composition of endemic Centaurea austro-anatolica and studies of its antimicrobial activity against multi-resistant bacteria, Acta Pharm. 59 (2009) 463-472.

the $0.5 \mathrm{McF}$ arland standard dilutions. Each bacterial suspension $100 \mu \mathrm{L}$ was spread on a Müller-Hinton agar plate. Sterile paper discs $(6 \mathrm{~mm}$ diameter) were impregnated with $20 \mu \mathrm{L}$ of each extract dissolved in the solvent used for extraction at $25 \mathrm{mg} \mathrm{mL}^{-1}$. The discs were allowed to dry and were then placed on the inoculated agar. The plates were incubated at appropriate temperature and time for the microorganisms, as mentioned above. Discs with hexane, chloroform, ethyl alcohol and ethyl acetate were used as controls. After incubation time, the zone of inhibition was measured. The experiments were performed in triplicate.

\section{RESULTS AND DISCUSSION}

A total of 28 compounds was detected in the chloroform extract using GC and GC/MS (Table I). The typical chromatogram can be seen in Figure I.

Components of the chloroform extract were separated into five classes, including oxygenated monoterpene hydrocarbons $(0.91 \%)$, sesquiterpene hydrocarbons $(3.14 \%)$, oxygenated sesquiterpenes $(60.54 \%)$, aromatic alcohols $(3.12 \%)$ and others $(32.29 \%)$. The chloroform extract consisted mainly of oxygenated sesquiterpenes $(60.54 \%)$. Caryophyllene oxide (21.32\%) and spathulenol (10.32\%) were the prevailing oxygenated sesquiterpenes.

Three Gram-negative test bacteria, four Gram-positive test bacteria, two yeasts and multi-resistant bacteria were used in this study. If the extracts had any effect on the

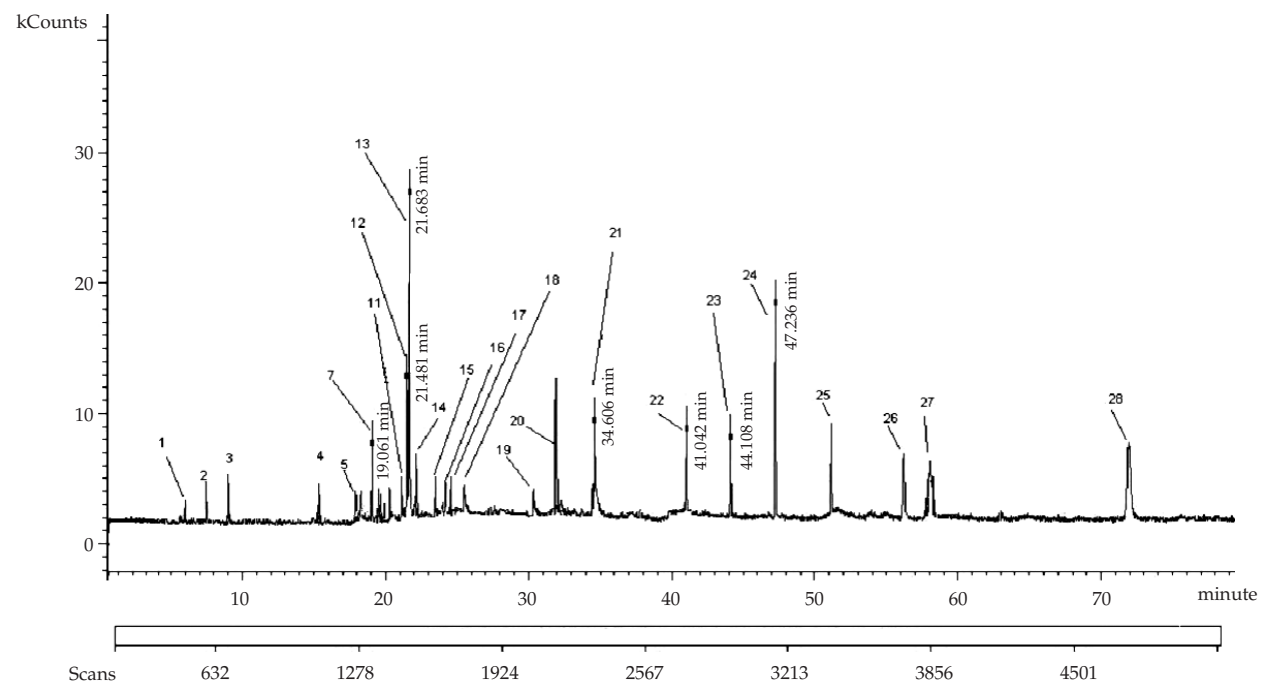

Fig. 1. Typical chromatogram of chloroform extract of C. austro-anatolica. For keys to the peaks see Table I. 
A. Ugur et al.: Chemical composition of endemic Centaurea austro-anatolica and studies of its antimicrobial activity against multi-resistant bacteria, Acta Pharm. 59 (2009) 463-472.

Gram-negative and Gram-positive test bacteria, its antibacterial activity was evaluated on multi-resistant strains of Stenotrophomonas maltophilia and various species of Staphylococcus, including CNS, respectively. The antibiotic resistance patterns of the multi-resistant bacteria are shown in Table II. The results obtained by evaluation of the antimicrobial activity of the extracts are shown in Table III.

Table I. Chemical compositions of the chloroform extract of C. austro-anatolica

\begin{tabular}{|c|c|c|c|}
\hline No. & Compound $^{\mathrm{a}}$ & Percentage $(\%)$ & Method \\
\hline 1 & 3-Penthyl-2,4-pentadien-1-ol & 0.91 & $\mathrm{~b}$ \\
\hline 2 & 5-Amino-2-methoxyphenol & 1.27 & $\mathrm{~b}$ \\
\hline 3 & $\alpha$-Ethyl- $p$-methoxybenzylalcohol & 1.85 & $\mathrm{~b}$ \\
\hline 4 & 2-Decenal & 1.37 & b, c \\
\hline 5 & Ascaridol & 0.96 & b, c \\
\hline 6 & 2-Buthyl-1-octanol & 0.87 & b, c \\
\hline 7 & 7-Tetradecene & 2.58 & $\mathrm{~b}$ \\
\hline 8 & Ascaridole epoxide & 0.92 & $b, c$ \\
\hline 9 & 2-Methyl-(Z)-4-tetradecene & 0.98 & $\mathrm{~b}$ \\
\hline 10 & $\alpha$-Cubebene & 1.54 & b, c \\
\hline 11 & $\beta$-Bourbonene & 1.60 & b, c \\
\hline 12 & Spathulenol & 10.86 & b, c \\
\hline 13 & Caryophyllene oxide & 21.32 & b, c \\
\hline 14 & Cubenol & 1.89 & b, c \\
\hline 15 & $\beta$-Eudesmol & 1.12 & b, c \\
\hline 16 & Isoaromadendrene epoxide & 0.87 & $b, c$ \\
\hline 17 & Ledene oxide-(11) & 0.94 & b, c \\
\hline 18 & trans-(Z)- $\alpha$-Bisabolene epoxide & 1.31 & $\mathrm{~b}$ \\
\hline 19 & Cedrane-8,13-diol & 1.17 & $\mathrm{~b}$ \\
\hline 20 & Hexahydro farnesyl acetone & 6.32 & b, c \\
\hline 21 & 2,6,10-Trimethyl-9-undecenal (adoxal) & 4.15 & $\mathrm{~b}$ \\
\hline 22 & 2-Methyl-1-hexadecanol & 3.28 & $\mathrm{~b}$ \\
\hline 23 & 4-Methyl-docosane & 2.46 & $\mathrm{~b}$ \\
\hline 24 & $n$-Tricosanol & 9.58 & b, c \\
\hline 25 & 11-(1-Ethyl propyl)-heneicosane & 2.81 & $\mathrm{~b}$ \\
\hline 26 & $n$-Heptacosanol & 3.97 & $b, c$ \\
\hline 27 & (Z)-5-Methyl-6-heneicosen-11-one & 4.39 & $\mathrm{~b}$ \\
\hline \multirow[t]{2}{*}{28} & Geranyl isovalerate & 8.71 & $\mathrm{~b}$ \\
\hline & Total & 100 & \\
\hline
\end{tabular}

a In DB-1 fused silica capillary column.

b - MS

c-Co-injection with authentic compound. 
A. Ugur et al: Chemical composition of endemic Centaurea austro-anatolica and studies of its antimicrobial activity against multi-resistant bacteria, Acta Pharm. 59 (2009) 463-472.

Table II. Antibiotic resistance patterns of S. maltophilia and Staphylococcus

\begin{tabular}{|c|c|}
\hline Strain & Resistance patterns \\
\hline S. maltophilia MU 23 & $\begin{array}{l}\text { MEZ, TIM, CAZ, FEP, CRO, CTX, KF, IPM, P, AK, TOB, NET, } \\
\text { CN, TE, NOR, C, TVA, AM, PRL, ATM, SAM, AMC }\end{array}$ \\
\hline S. maltophilia MU 25 & $\begin{array}{l}\text { MEZ, TIM, CAZ, FEP, CRO, CTX, KF, IPM, P, AK, TOB, NET, } \\
\text { CN, TE, CIP, NOR, C, TVA, AM, PRL, ATM, SAM, AMC }\end{array}$ \\
\hline S. maltophilia MU 52 & $\begin{array}{l}\text { MEZ, TIM, CAZ, FEP, CRO, CTX, KF, IPM, P, AK, TOB, NET, } \\
\text { CN, TE, CIP, NOR, C, TVA, AM PRL, ATM, SAM, AMC }\end{array}$ \\
\hline S. maltophilia MU 53 & $\begin{array}{l}\text { MEZ, TIM, CAZ, FEP, CRO, CTX, KF, IPM, P, NOR, C, TVA, } \\
\text { AM, PRL, ATM, SAM, AMC }\end{array}$ \\
\hline S. maltophilia MU 63 & $\begin{array}{l}\text { MEZ, TIM, CAZ, FEP, CRO, CTX, KF, IPM, P, AK, TOB, NET, } \\
\text { CN, TE, CIP, NOR, C, TVA, AM, PRL, ATM, SAM, AMC }\end{array}$ \\
\hline S. maltophilia MU 64 & $\begin{array}{l}\text { MEZ, TIM, CAZ, FEP, CRO, CTX, KF, IPM, P, AK, TOB, NET, } \\
\text { CN, TE, CIP, NOR, C, SXT, TVA, AM, PRL, ATM, SAM, } \\
\text { AMC }\end{array}$ \\
\hline S. maltophilia MU 69 & $\begin{array}{l}\text { MEZ, TIM, CAZ, FEP, CRO, CTX, KF, IPM, P, AK, TOB, NET, } \\
\text { CN, TE, NOR, C, SXT, TVA, AM, PRL, ATM, SAM, AMC }\end{array}$ \\
\hline S.maltophilia MU 94 & $\begin{array}{l}\text { MEZ, TIM, CAZ, FEP, CRO, CTX, KF, IPM, P, AK, TOB, NET, } \\
\text { CN, TE, NOR, C, TVA, AM, PRL, ATM, SAM, AMC }\end{array}$ \\
\hline S. maltophilia MU 99 & $\begin{array}{l}\text { MEZ, TIM, CAZ, FEP, CRO, CTX, KF, IPM, P, AK, TOB, NET, } \\
\text { CN, TE, NOR, C, SXT, TVA, AM, PRL, ATM,SAM, AMC }\end{array}$ \\
\hline S. maltophilia MU 136 & $\begin{array}{l}\text { MEZ, TIM, CAZ, FEP, CRO, CTX, KF, IPM, P, AK, TOB, NET, } \\
\text { CN, TE, NOR, C, TVA, AM, PRL, ATM, SAM, AMC }\end{array}$ \\
\hline S. maltophilia MU 137 & $\begin{array}{l}\text { MEZ, TIM, CAZ, FEP, CRO, CTX, KF, IPM, P, AK, TOB, NET, } \\
\text { CN, TE, CIP, NOR, C, TVA, AM, PRL, ATM, SAM, AMC }\end{array}$ \\
\hline Staphylococcus xylosus MU 34 & $\mathrm{P}, \mathrm{AK}, \mathrm{DA}, \mathrm{E}, \mathrm{CN}, \mathrm{OX}, \mathrm{TEC}$ \\
\hline S. xylosus MU 35 & P, DA, E, C, OX, TE \\
\hline S. xylosus MU 37 & $\mathrm{P}, \mathrm{AK}, \mathrm{DA}, \mathrm{E}, \mathrm{CN}, \mathrm{TEC}, \mathrm{TE}$ \\
\hline S. xylosus MU 42 & $\mathrm{P}, \mathrm{AK}, \mathrm{DA}, \mathrm{CN}, \mathrm{OX}, \mathrm{TE}$ \\
\hline S. aureus MU 38 & $\mathrm{P}, \mathrm{AK}, \mathrm{DA}, \mathrm{CN}, \mathrm{ME}, \mathrm{TEC}, \mathrm{TE}, \mathrm{OX}$ \\
\hline S. aureus MU 40 & $\mathrm{P}, \mathrm{AK}, \mathrm{CN}, \mathrm{C}, \mathrm{ME}, \mathrm{OX}, \mathrm{TE}$ \\
\hline S. aureus MU 46 & $\mathrm{P}, \mathrm{AK}, \mathrm{DA}, \mathrm{E}, \mathrm{CN}, \mathrm{TE}, \mathrm{OX}$ \\
\hline Staphylococcus sp. MU 28 & $\mathrm{P}, \mathrm{AK}, \mathrm{DA}, \mathrm{E}, \mathrm{CN}, \mathrm{TE}$ \\
\hline S. capitis MU 27 & $\mathrm{P}, \mathrm{AK}, \mathrm{DA}, \mathrm{E}, \mathrm{CN}, \mathrm{TE}$ \\
\hline S. epidermidis MU 30 & $\mathrm{P}, \mathrm{AK}, \mathrm{DA}, \mathrm{CN}, \mathrm{OX}, \mathrm{TEC}, \mathrm{TE}$ \\
\hline S. lentus MU 43 & $\mathrm{P}, \mathrm{AK}, \mathrm{DA}, \mathrm{CN}, \mathrm{OX}, \mathrm{TE}$ \\
\hline
\end{tabular}

Antibiotics dosing 6-mm discs (in $\mu \mathrm{g} \mathrm{cm}^{-2}$ ) except penicillin (in $\mathrm{U} \mathrm{cm}^{-2}$ ): MEZ - mezlocillin (75), TIM - ticarcillin + clavulanic acid (75 + 10), CAZ - ceftazidime (30), FEP - cephepim (30), CRO - ceftriaxone (30), CTX - cefotaxime (30), KF - cephalothin (30), IPM - imipenem (10), P - penicillin (10 U), AK - amikacin (30), TOB - tobramycin (10), NET - netilmicin (30), CN - gentamicin (10), TE - tetracycline (30), NOR - norfloxacin (10), C - chloramphenicol (30), TVA - trovafloksasin (10), AM - ampicillin (10), PRL - piperacillin (100), ATM - aztreonam (30), SAM - sulbactam + ampicillin $(10+10)$, AMC - amoxicillin + clavulanic acid $(20+10)$, CIP - ciprofloxacin (5), SXT trimetoprim + sulfamethoxazole $(1.25$ + 23.75), DA - clindamycin (2); E - erythromycin (15); ME - methicillin (5); OX - oxacillin (1); TEC - teicoplanin (30). 
A. Ugur et al.: Chemical composition of endemic Centaurea austro-anatolica and studies of its antimicrobial activity against multi-resistant bacteria, Acta Pharm. 59 (2009) 463-472.

Table III. Antimicrobial activity of C. austro-anatolica extracts

\begin{tabular}{|c|c|c|c|c|}
\hline \multirow[b]{2}{*}{ Strain } & \multicolumn{4}{|c|}{ Inhibition zone $(\mathrm{mm})$} \\
\hline & $\begin{array}{l}\text { Hexane } \\
\text { extract }\end{array}$ & $\begin{array}{l}\text { Chloroform } \\
\text { extract }\end{array}$ & $\begin{array}{c}\text { Ethanolic } \\
\text { extract }\end{array}$ & $\begin{array}{l}\text { Ethyl ace- } \\
\text { tate extract }\end{array}$ \\
\hline E. aerogenes RSKK 720 & - & 13 & - & - \\
\hline P. aeruginosa ATCC 27853 & - & 15 & 13 & - \\
\hline E. coli ATCC 25922 & - & 20 & 12 & - \\
\hline S. maltophila MU 23 & NT & 19 & 13 & NT \\
\hline S. maltophila MU 25 & NT & 12 & 9 & NT \\
\hline S. maltophila MU 52 & NT & 12 & 14 & NT \\
\hline S. maltophila MU 53 & NT & 20 & 19 & NT \\
\hline S. maltophila MU 63 & NT & 12 & 15 & NT \\
\hline S. maltophila MU 64 & NT & 20 & 20 & NT \\
\hline S. maltophila MU 69 & NT & 11 & 10 & NT \\
\hline S. maltophila MU 94 & NT & 19 & 13 & NT \\
\hline S. maltophila MU 99 & NT & 20 & 11 & NT \\
\hline S. maltophila MU 136 & NT & 12 & 18 & NT \\
\hline S. maltophila MU 137 & NT & 11 & 15 & NT \\
\hline M. luteus NRRL B-4375 & 9 & 19 & - & - \\
\hline B. subtilis ATCC 6633 & - & 18 & - & - \\
\hline S. mutans CNCTC 8/77 & - & 13 & - & - \\
\hline S. aureus ATCC 25923 & - & 17 & 22 & - \\
\hline S. capitis MU 27 & - & 21 & - & NT \\
\hline Staphylococcus sp. MU 28 & - & 15 & - & NT \\
\hline S. epidermidis MU 30 & - & 16 & 18 & NT \\
\hline S. xylosus MU 34 & - & 21 & 20 & NT \\
\hline S. xylosus MU 35 & - & 19 & 22 & NT \\
\hline S. xylosus MU 37 & - & 20 & 21 & NT \\
\hline S. xylosus MU 42 & - & 16 & 21 & NT \\
\hline S. lentus MU 43 & - & 20 & 22 & NT \\
\hline S. aureus MU 38 & - & 14 & 18 & NT \\
\hline S. aureus MU 40 & - & 18 & 15 & NT \\
\hline S. aureus MU 46 & - & 21 & 18 & NT \\
\hline C. albicans ATCC 10239 & - & - & - & - \\
\hline C. tropicalis RSKK 665 & - & 12 & 12 & - \\
\hline
\end{tabular}

NT - not tested, (-) - no activity 
A. Ugur et al: Chemical composition of endemic Centaurea austro-anatolica and studies of its antimicrobial activity against multi-resistant bacteria, Acta Pharm. 59 (2009) 463-472.

Since hexane and ethyl acetate extracts had no effect on Gram-negative bacteria, their antibacterial activities were not determined on antibiotic resistant S. maltophilia strains. Hexane extract showed no inhibition effect on Gram-positive bacteria either, except $M$. luteus or multi-resistant strains of various species of Staphylococcus. Chloroform extract inhibited the growth of all microorganisms, except C. albicans and the inhibition zones ranged between 11-21 mm. Ethanolic extract had antimicrobial effect on many of the microorganisms and the inhibition zones ranged between 9-22 $\mathrm{mm}$. Ethyl acetate extract did not inhibit the growth of either Gram-positive or Gram-negative bacteria. The extracts did not exert any antifungal activity against C. albicans.

In this study, all strains of multi-resistant S. maltophilia tested were inhibited by ethanol and chloroform extracts.

The most effective extract was the chloroform extract, which exhibited a significant antimicrobial activity against all the microorganisms tested except C. albicans. This extract exhibited a significant effect against multi-resistant strains of S. maltophilia with 11-20 mm inhibition zones. Also, this extract exhibited bactericidal effect against multi-resistant Staphylococcus aureus and CNS.

The results indicate that the chloroform extract of $C$. austro-anatolica has a capacity to inhibit the growth of pathogenic bacteria. Sesquiterpenes, which were found in appreciable amounts, have been reported to have potent antimicrobial activity and to play a critical role in plant defense mechanisms (14). The potent activity of the chloroform extract might be attributed to its high oxygenated sesquiterpene content (60.54\%).

Caryophyllene oxide, the most abundant constituent of the extract, is known to exhibit antibacterial activity (15). It is thought that because of its high caryophyllene oxide content, the chloroform extract of C. austro-anatolica possesses high total antimicrobial activities.

\section{CONCLUSIONS}

Our study can be considered as the first document of the in vitro antimicrobial features and chemical composition of $C$. austro-anatolica. The study has shown that the chloroform extract of C. austro-anatolica may be useful as an alternative antimicrobial agent against multi-resistant S. maltophilia, S. aureus and coagulase negative Straphylococci.

Acknowledgements. - This work was supported by Mugla University Research Funds. The authors thank Associated Prof. Dr. Omer Varol, Department of Biology, Faculty of Arts and Sciences, University of Mugla, for identification of the plant material collected.

\section{REFERENCES}

1. T. Baytop, Therapy with Medicinal Plants in Turkey (Past and Present), Nobel Tip Kitabevi, Istanbul 1999, p. 316.

2. C. Karamenderes, S. Khan, B. L. Tekwani, M. R. Jacob and I. A. Khan, Antiprotozoal and antimicrobial activities of Centaurea L. species growing in Turkey, Pharm. Biol. 44 (2006) 534-539; DOI: $10.1080 / 13880200600883080$. 
A. Ugur et al: Chemical composition of endemic Centaurea austro-anatolica and studies of its antimicrobial activity against multi-resistant bacteria, Acta Pharm. 59 (2009) 463-472.

3. C. Koukoulitsa, G. D. Geromichalos and H. Skaltsa, VolSurf analysis of pharmacokinetic properties for several antifungal sesquiterpene lactones isolated from Greek Centaurea sp., J. Comput. Aid. Mol. Des. 19 (2005) 617-623; DOI: 10.1007/s10822-005-9018-y.

4. N. Garbacki, V. Gloaguen, J. Damas, P. Bodart, M. Tits and L. Angenat, Anti-inflammatory and immunological effects of Centaurea cyanus flower-heads, J. Ethnopharmacol. 68 (1999) 235-241; DOI: 10.1016/S0378-8741(99)00112-9.

5. E. Yesilada, E. Sezik, G. Honda, Y. Takaishi, Y. Takeda and T. Tanaka, Traditional medicine in Turkey IX: Folk medicine in Northwest Anatolia, J. Ethnopharmacol. 64 (1999) 195-210; DOI: 10.1016/S0378-8741(98)00133-0.

6. J. F. Severino, K. Stich and G. Soja, Ozone stress and antioxidant substances in Trifolium repens and Centaurea jacea leaves, Environ. Pollut. 146 (2007) 707-714; DOI: 10.1016/j.envpol.2006.04.006.

7. G. Rusak, M. Krajacic and N. Plese, Inhibition of tomato bushy stunt virus infection using a quercetagetin flavonoid isolated from Centaurea rupestris L., Antiviral Res. 36 (1997) 125-129; DOI: 10.1016/S0166-3542(97)00045-4.

8. G. Stamatis, P. Kyriazopoulos, S. Golegou, A. Basayiannis, S. Skaltsa and H. Skaltsa, In vitro anti-Helicobacter pylori activity of Greek herbal medicines, J. Ethnopharmacol. 88 (2003) 175-179; DOI: 10.1016/S0378-8741(03)00217-4.

9. M. Shoeb, S. M. MacManus, M. Jaspars, J. Trevidu, L. Nahar, P. Kong-Thoo-Lin and S. D. Sarker, Montamine, a unique dimeric indole alkaloid, from the seeds of Centaurea montana (Asteraceae), and its in vitro cytotoxic activity against the $\mathrm{CaCo} 2$ colon cancer cells, Tetrahedron 62 (2006) 11172-11177; DOI: 10.1016/j.tet.2006.09.020.

10. G. Wagenitz, Centaurea L., in Flora of Turkey and The East Aegean Islands (Ed. P. H. Davis), Vol. 5, Edinburgh University Press, Edinburgh 1975, pp. 465-585.

11. R. P. Adams, Identification of Essential Oils Components by Gas Chromatography/Quadrupole Mass Spectroscopy, Allured Publishing Corporation, Carol Stream, (IL) 2001, pp. 9-456.

12. C. H. Collins, P. M. Lyne and J. M. Grange, Microbiological Methods, 7th ed., Butterworths, London 1995, pp. 168-186.

13. P. R. Murray, E. J. Baron, M. A. Pfaller, F. C. Tenover and R. H. Yolke, Manual of Clinical Microbiology, Vol. 6, American Society for Microbiology, Washington D.C. 1995, pp. 1526-1544.

14. M. M. Oliva, M. S. Demo, A. G. Lopez, M. L. Lopez and J. Zygadlo, Antimicrobial activity and composition of Hyptis mutabilis essential oil, J. Herbs Spices Med. Plants 11 (2005) 59-65; DOI: 10.1300/J044v11n04_07.

15. P. Magiatis, A. L. Skaltsounis, I. Chinou and S. Haroutounian, Chemical composition and in-vitro antimicrobial activity of the essential oils of three Greek Achillea Species, Z. Naturforsch. 57c (2002) 287-290.

$S A \check{Z} E T A K$

\section{Kemijski sastav endemske biljke Centaurea austro-anatolica $\mathrm{i}$ ispitivanje antimikrobnog djelovanja protiv multi-rezistentnih bakterija}

AYSEL UGUR, NURDAN SARAC, OZGUR CEYLAN i M. EMIN DURU

Heksanski, kloroformski, etil-acetatni i etanolni ekstrakti vršnih dijelova biljke $C$. austro-anatolica Hub.-Mor. (Asteraceae) ispitivani su na antimikrobno djelovanje protiv multi-rezistentnih bakterija, koristeći difuzijsku metodu na papirnom disku. Klorofor- 
A. Ugur et al: Chemical composition of endemic Centaurea austro-anatolica and studies of its antimicrobial activity against multi-resistant bacteria, Acta Pharm. 59 (2009) 463-472.

mski ekstrakt pokazao je značajno antibakterijsko djelovanje protiv svih testiranih bakterija. Kemijski sastav tog ekstrakta određivan je plinskom kromatografijom (GC) i plinskom kromatografijom-spektrometrijom masa (GC-MS). Najvažniji sastojci ekstrakta bili su kariofilen oksid (21,32\%), spatulenol (10,86\%), n-trikozanol $(9,58 \%)$ i geranil izovalerat $(8,71 \%)$.

Ključne riječi: Centaurea austro-anatolica (Asteraceae), kemijski sastav, antimikrobno djelovanje

Department of Biology, Faculty of Arts and Sciences, Mugla University, 48121 Kotekli-Mugla, Turkey

Medical Laboratory Program, Vocational School of Health Services, Mugla University, 48700

Marmaris-Mugla, Turkey

Department of Nursing, Health College, Usak University, 64100 Usak, Turkey

Department of Chemistry, Faculty of Arts and Sciences, Mugla University, 48121 Kotekli-Mugla, Turkey 